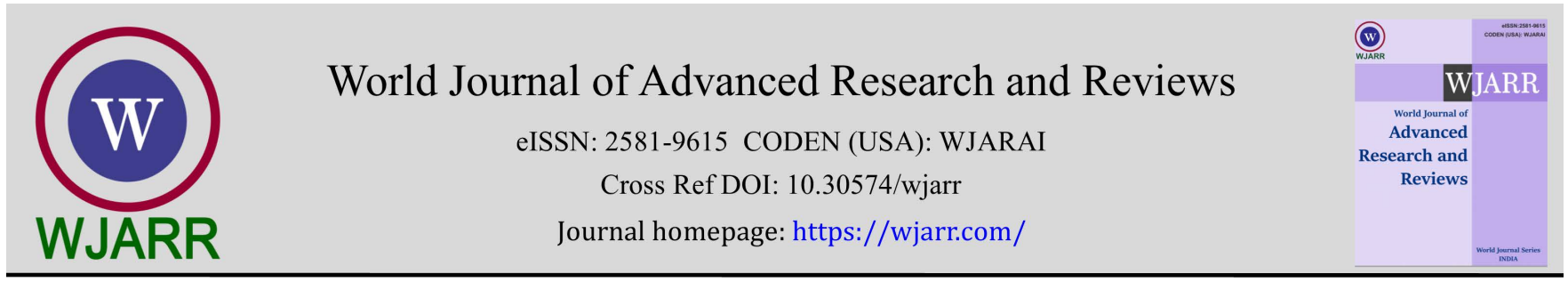

(RESEARCH ARTiClE)

Check for updates

\title{
Correlation between knowledge and medical waste management practices of puskesmas officers in Medan City
}

\author{
Daniel Jonathan Siagian ${ }^{1 *}$, Dr. Sulistiawati, Dr. M.Kes 2, Deby Kusumaningrum and Dr. M. Si Sp.MK ${ }^{3}$ \\ ${ }^{1}$ Airlangga University, Surabaya, Indonesia. \\ 2 Department of Public Health, Airlangga University, Surabaya, Indonesia. \\ 3 Department of Microbiology, Airlangga University, Surabaya, Indonesia.
}

World Journal of Advanced Research and Reviews, 2022, 13(02), 022-026

Publication history: Received on 06 December 2021; revised on 07 January 2022; accepted on 09 January 2022

Article DOI: https://doi.org/10.30574/wjarr.2022.13.2.0026

\begin{abstract}
Health care industry has contributed to the increasing amount of medical waste. It is very important for health care providers to have the necessary knowledge to practice medical waste management. The study aims to determine the correlation between knowledge and solid medical waste management practices by city health center (puskesmas) officers in Medan City in 2021. This study was an analytical observational study and was collected using questionnaires to 41 puskesmas officers in Medan City, North Sumatra, Indonesia. The independent variable was knowledge of puskesmas officer in solid medical waste management and the dependent variable was practice of puskesmas officer in solid medical waste management. The result is there are puskesmas officers who have less knowledge and less practice as many as 2 respondents (4,9\%), puskesmas officers who have less knowledge and good practice as many as 6 respondents $(14,6 \%)$, puskesmas officers who have good knowledge and good practice as many as 1 respondent $(2,4 \%)$, and puskesmas officers who have good knowledge and good practice as many as 32 respondents (78\%). The results of the statistical test obtained a p-value of 0.032 , so there is correlation between the level of knowledge and solid medical waste management practices at puskesmas in Medan City in 2021. To improve knowledge and practice of medical waste management, it is recommended for puskesmas officers to attend training and implement the standard operating procedures and for the government, it is recommended for carrying out training, providing adequate temporary disposal sites, and supervising medical waste management.
\end{abstract}

Keywords: Knowledge; Practices; Solid Medical Waste; Puskesmas Officer

\section{Introduction}

The growth of the healthcare industry in Indonesia has contributed to an increase of medical waste [1]. Data shows that the quantity of curative injection equipment waste in Indonesia is estimated at around 300 million per year, with $376,089 \mathrm{~kg}$ annually of solid medical waste produced annually in Medan, as one of the largest cities in Indonesia [2]. However, there are still limited resources for implementing effective waste management in developing countries [3]. Most health care institutions in developing countries are constrained by technological, economic, social challenges and the lack of adequate staff training in waste management [4].

Medical waste must be managed in an appropriate and adequate manner because poor waste handling practices and unsafe disposal methods harm the officers, the public, and the environment [5]. On the other hand, there is limited knowledge about the symptoms and health effects of individuals that exposed to waste of health care [6]. The World Health Organization estimates that every year there are between 8 and 16 million new cases of Hepatitis B virus, 2.3 -

\footnotetext{
* Corresponding author: Daniel Jonathan Siagian

Airlangga University, Surabaya, Indonesia.

Copyright $(2022$ Author(s) retain the copyright of this article. This article is published under the terms of the Creative Commons Attribution Liscense 4.0.
} 
4.7 million cases of Hepatitis C virus and 80,000 - 160,000 cases of HIV due to unsafe injection disposal and very poor waste management systems [7].

Everyone who is exposed to hazardous waste from health facilities is likely to be at risk [8]. The ability to manage medical waste by health care providers requires knowledge as the basis [9]. It is imperative for healthcare providers to have the necessary knowledge to practice medical waste management properly to protect themselves, society and more importantly the environment [10]. Lack of knowledge and practice of the puskesmas officers risks endangering health care officers, patients, and the environment [11].

Puskesmas is a health facility that provides direct services to the community which in its activities produces medical waste in both solid and liquid form [12]. Based on the data gathered from the Ministry of Health in 2019, there are 10.062 puskesmas in Indonesia and there are 41 units of puskesmas in Medan City [13]. Each puskesmas have responsibilities related to the waste generated [14]. However, there are only $6.89 \%$ of puskesmas that have adequate medical waste management practices and there are still many puskesmas that do not manage waste according to standards [15]. Based on the description above, the researcher is interested in examining the correlation between and medical waste management practices of puskesmas officers in Medan City using chi-square.

\section{Material and methods}

This study is an analytic observational study with a cross-sectional research design. The study was conducted at puskesmas in Medan City, North Sumatra, Indonesia. The research was carried out from July 2020 to December 2021. The population of the research was gathered from the amount of public health care in Medan city. With the use of total sampling technique, the sample of the research is the puskesmas officers who in charge of solid medical waste management with the amount of 41 employees. There are 2 (two) variables in this research, the independent variable is the knowledge of the officer in solid medical waste management in Medan City and the dependent variable is the practice of the officer of the officer in solid medical waste management in Medan City. The knowledge and practice variables were collected by questionnaire. The knowledge questionnaire contains of 12 questions and the practice questionnaire contains 10 questions. This questionnaire was about the process of identification, separation, labeling, transportation, storage, and disposal/destruction of solid medical waste. The data were proceeded by several stages, start from editing, coding, scoring, entry, tabulating, and cleaning, and were analyzed by using univariate analysis and bivariate analysis. Univariate Analysis was carried out based on each variable by calculating the frequency distribution to know the characteristics of the research subject. Bivariate Analysis was conducted to determine the relationship between two variables consisting of the independent variable and the dependent variable.

\section{Results}

\subsection{Sample Characteristics}

The study was conducted to 41 puskesmas officers who in charge for medical waste management in Medan City. The data collection was carried out in February - March 2021. Table 1 presents the characteristics of the subject in this research with observed frequencies and percentages. Based on the table, most of the officers are female (82.9\%) and in age of 41-50 years old. University is the place where $63.4 \%$ of the officers graduated. All the officers are civil servants with work 7 hours/day. Most of the officers who in charge for medical waste management are sanitarian officer and work $<11$ years in the puskesmas. Most of the officers have never attended training (63.4\%).

Table 1 Characteristics of the subjects of the research

\begin{tabular}{|l|l|c|c|}
\hline Characteristics & Criteria & Frequency & Percentage \\
\hline \multirow{4}{*}{ Age } & $<31$ years old & 2 & $4.9 \%$ \\
\cline { 2 - 4 } & $31-40$ years old & 11 & $26.8 \%$ \\
\cline { 2 - 4 } & $41-50$ years old & 16 & $39 \%$ \\
\cline { 2 - 4 } & $>50$ years old & 12 & $29.3 \%$ \\
\hline \multirow{3}{*}{ Gender } & Male & 7 & $17.1 \%$ \\
\cline { 2 - 4 } & Female & 34 & $82.9 \%$ \\
\hline \multirow{3}{*}{ Education } & University & 26 & $63.4 \%$ \\
\cline { 2 - 4 } & Academy & 15 & $36.6 \%$ \\
\hline
\end{tabular}




\begin{tabular}{|l|l|c|c|}
\hline \multirow{4}{*}{ Length of work } & $<11$ years & 16 & $39 \%$ \\
\cline { 2 - 4 } & $11-20$ years & 9 & $22 \%$ \\
\cline { 2 - 4 } & $21-30$ years & 9 & $22 \%$ \\
\cline { 2 - 4 } & $>30$ years & 7 & $17 \%$ \\
\hline \multirow{4}{*}{ Position } & Sanitarian officer & 39 & $95.1 \%$ \\
\cline { 2 - 4 } & Doctor & 1 & $2.4 \%$ \\
\cline { 2 - 4 } & Health promotion & 1 & $2.4 \%$ \\
\hline \multirow{3}{*}{ Employment status } & $<7$ hours & 0 & $0 \%$ \\
\cline { 2 - 4 } & 7 hours & 41 & $100 \%$ \\
\cline { 2 - 4 } & $>7$ hours & 0 & $0 \%$ \\
\cline { 2 - 4 } & Civil servants & 41 & $100 \%$ \\
\hline \multirow{3}{*}{ Training Participation } & Non civil servants & 0 & $0 \%$ \\
\cline { 2 - 4 } & Never attended training & 26 & $63.4 \%$ \\
\cline { 2 - 4 } & Have attended training & 15 & $36.6 \%$ \\
\hline
\end{tabular}

\subsection{Bivariate Analysis}

Bivariate analysis explains the correlation between knowledge and the practice as independent and dependent variable. The method used is chi-square with $95 \%$ confidence level ( $\mathrm{p}$-value $<0.05$ ). Table 2 shows that there are puskesmas officers in Medan City who have less knowledge and less practices as many as 2 respondents (4.9\%). There are 6 respondents (14.6\%) of puskesmas officers in Medan City who have less knowledge and good practice. There are 1 respondent (2.4\%) of puskesmas officers in Medan City who have good knowledge and less practice and 32 respondents (78\%) with good knowledge and good practice. The results of the chi-square test obtained $\mathrm{p}=0.032$ which indicates that there is correlation between the knowledge of puskesmas officers with solid medical waste practices at puskesmas in Medan City.

Table 2 Determinants of Practices (an analysis by Chi Square Statistic Test)

\begin{tabular}{|l|c|c|c|c|c|}
\hline \multirow{2}{*}{ Variable } & \multicolumn{4}{|c|}{ Practice } & \multirow{2}{*}{ p-value } \\
\cline { 2 - 5 } & \multicolumn{2}{|l|}{ Less } & \multicolumn{2}{l|}{ Good } & \\
\cline { 2 - 5 } & $\mathbf{N}$ & $\mathbf{\%}$ & $\mathbf{N}$ & $\mathbf{\%}$ & \\
\hline Knowledge & 2 & 4.9 & 6 & 14.6 & \multirow{2}{*}{0.032} \\
\hline Less & 2 & 2.4 & 32 & 78 & \\
\hline Good & 1 & & \\
\hline
\end{tabular}

\section{Discussion}

The results showed that most of the officers already have good knowledge with 33 respondents (80.5\%) have good knowledge and 8 respondents (19.5\%) have less knowledge. Most of the respondents already have good practices with 38 respondents (92.7\%) and 3 respondents (7.3\%) have less medical waste management practices. However, medical waste management have a comprehensive management process begins with identification, waste sorting, container sorting, waste treatment, and waste transportation. Based on the results of the knowledge questionnaire, it was found that most of the respondents have correct answers on the questions related to waste identification, sorting, and storage. But there are respondents who had wrong answers on the questions related to the diseases that can be caused by waste hazards, waste transport trolleys, the use of incinerators, and special plastic coatings. On the results of the practice questionnaire, it was found that most of the respondents have practiced good waste management starting from waste identification, sorting, storage, and waste treatment. But the respondents have incorrect answers related to transporting waste from temporary shelter with 28 respondents had incorrect answers.

Based on table 2, there are 32 puskesmas officers who have good knowledge and good practice of respondents in managing solid medical waste in Medan City. However, there are still respondents who have less knowledge or less practices in managing solid medical waste at the puskesmas. This result could be happened because of the factors that 
affect knowledge or practice. Based on the research conducted, there are 8 (19.5\%) respondents who have less knowledge that have never attended training and there are $3(7.3 \%)$ respondents who have less practices that have never attended training. Training can increase certain knowledge and skills so that employees become more skilled [16] and able to carry out tasks according to standards responsibly and training can prepare workers with the knowledge and skills required for today's jobs [17]. Training is made to increase the insight, knowledge, skills of the employees and could change the attitudes and behavior of employees to be more productive [18].

Based on table 2, the results of the Chi-Square test, $p=0.032$. So, it can be concluded that there is a correlation between the level of knowledge and solid medical waste management practices at puskesmas in Medan City. This is in line with the others research which states that there is a relationship between knowledge and actions of health workers regarding hospital medical waste management [19] and in line with another research which states that there is a relationship between knowledge and practice of medical waste collectors [20]. To act in disposing of medical waste in its proper way, there are efforts that can be made to increase knowledge by providing training. Because medical waste requires special handling to minimize the negative impacts that arise.

\section{Conclusion}

Most of the puskesmas officers in Medan City already have good knowledge and good practice in solid medical waste management. However, there is still another puskesmas officers who have less knowledge and less practice in solid medical waste management. By this study, the result is there is a correlation between the level of knowledge and solid medical waste management practices at puskesmas in Medan City. So, this study could be the source of information in enriching the development of science and knowledge in terms of solid medical waste management at puskesmas in Medan City and provide the overview on the current situation, and how to manage and increase the knowledge and the practices of the officers.

\section{Compliance with ethical standards}

\section{Acknowledgments}

This study would not have been possible without the support from my university, Airlangga University, my supervisor and examiner, Dr. Sulistiawati, dr., M. Kes, Deby Kusumaningrum dr. M.Si., Sp MK, and Dr. Lilik Djuari dr., M.Kes.

\section{Disclosure of conflict of interest}

There is no conflict of interest in this research.

\section{Statement of ethical approval}

Research ethical issues were addressed carefully on this study. The research ethical clearance approval letter was obtained from the Health Research Ethics Committee Universitas Airlangga School of Medicine Surabaya, Indonesia, No. 57/EC/KEPK/FKUA/2021, on March 18, 2021.

\section{Statement of informed consent}

Informed consent was obtained from all individual participants included in the study.

\section{References}

[1] Rahno D, Roebijoso J, Leksono AS. Pengelolaan Limbah Medis Padat Di Puskesmas Borong Kabupaten Manggarai Timur Propinsi Nusa Tenggara Timur. Indonesian Journal of Environment and Sustainable Development. 2015; $6(1)$.

[2] Simarmata V. Model Pengelolaan Limbah Padat Medis Rumah Sakit di Kota Medan. 2018.

[3] Caniato M, Tudor T, Vaccari M. International governance structures for health-care waste management: A systematic review of scientific literature. Journal of Environmental Management. 15 Apr 2015; 153: 93 -107.

[4] Alagöz AZ, Kocasoy G. Improvement and modification of the routing system for the health-care waste collection and transportation in Istanbul. Waste Management. 1 Jan 2008; 28(8): 1461-71. 
[5] Hakim SA, Mohsen A, Bakr I. Knowledge, attitudes and practices of health-care personnel towards waste disposal management at Ain Shams University Hospitals, Cairo.

[6] Patwary MA, O'Hare WT, Sarker MH. An illicit economy: Scavenging and recycling of medical waste. Journal of environmental management. 1 Nov 2011; 92(11): 2900-6.

[7] Hasibuan RR. Hubungan Pengetahuan dan Sikap Petugas Cleaning Service dengan Penanganan Limbah Medis di Rumah Sakit Umum Daerah Dr. Pirngadi Medan Tahun. 2018.

[8] Purba ES, Khairunnisa C. Hubungan Pengetahuan, Sikap Dan Ketersediaan Fasilitas Dengan Praktik Petugas Pengumpul Limbah Medis Di Rumah Sakit Umum Cut Meutia Kabupaten Aceh Utara Tahun 2015. Averrous: Jurnal Kedokteran dan Kesehatan Malikussaleh. 16 Feb 2018; 1(2): 23-37.

[9] Sudiharti S, Solikhah S. Hubungan pengetahuan dan sikap dengan perilaku perawat dalam pembuangan sampah medis di rumah sakit pku muhammadiyah yogyakarta. Kes Mas: Jurnal Fakultas Kesehatan Masyarakat Universitas Ahmad Daulan. 2011; 6(1): 24951.

[10] Nagaraju B, Padmavathi GV, Puranik DS, Shantharaj MP, Sampulatha SP. A study to assess the knowledge and practice on bio-medical waste management among the health care providers working in PHCs of Bagepalli Taluk with the view to prepare informational booklet. International journal of medicine and biomedical research. 7 Aug 2013; 2(1): 28-35.

[11] Nursamsi N, Thamrin T, Efizon D. Analisis Pengelolaan Limbah Medis Padat Puskesmas Di Kabupaten Siak. Dinamika Lingkungan Indonesia. 2017; 4(2): 86-98.

[12] Astawa I. Gambaran Pengelolaan Limbah Medis Padat di Unit Pelaksana Teknis Kesmas Gianyar II Kabupaten Gianyar (Doctoral dissertation, Jurusan Kesehatan Lingkungan).

[13] Pusat Data dan Informasi Kementerian Kesehatan, RI. Data Dasar Puskesmas Provinsi Sumatera Utara.

[14] Mirawati M, Budiman B, Tasya Z. Analisis sistim pengelolaan limbah medis padat di puskesmas pangi kabupaten parigi moutong. Jurnal Kolaboratif Sains. 15 Sep 2019; 2(1).

[15] Direktorat Jenderal Kesehatan Masyarakat. Pengolahan Limbah Medis Fasyankes Menjadi Perhatian Khusus.

[16] Mangkuprawira T. Manajemen sumber daya manusia strategik.

[17] Kandou EE. Pengaruh Pelatihan Dan Pengembangan Karyawan Terhadap Produktivitas Kerja Karyawan (Studi Pada PT. Air Manado). ACTA DIURNA KOMUNIKASI. 16 Aug 2013; 2(3).

[18] Simamora H. Manajemen Sumber Daya Manusia Edisi III. Jakarta: STIE YKPN. 2004.

[19] Wahyu W. Hubungan Antara Pengetahuan dan Sikap dengan Tindakan Petugas Kesehatan dalam Upaya Pengelolaan Sampah Medis di Rumah Sakit Griya Husada Madiun Tahun 2017 (Doctoral dissertation, Stikes Bhakti Husada Mulia). 2017.

[20] Jasmati J, Syafar HM, Jafar N. Hubungan Pengetahuan, Sikap dan Ketersediaan Fasilitas Dengan Praktik Petugas Pengumpul Limbah Medis di RSUD Abdul Wahab Sjahranie Samarinda. Jurnal Kesehatan Masyarakat UNHAS. 2012; 9(1): 1-14. 